\title{
KEWENANGAN PEMERINTAH KOTA DENPASAR DALAM PENERAPAN JALUR KHUSUS SEPEDA
}

\author{
I Putu Aldi Wira Kusuma, I Nyoman Gede Sugiartha, Luh Putu Suryani \\ Fakultas Hukum, Universitas Warmadewa, Denpasar-Bali, Indonesia \\ nyomansugiarta14@gmail.com, putusuryani099@gmail.com
}

\begin{abstract}
Abs trak
Mewujudkan Kota Denpasar yang ramah lingkungan menjadi salah satu konsep penyeimbang dalam pembangunan kota yang berwawasan lingkungan. Mengganti moda transportasi ke transportasi yang ramah lingkungan seperti penggunaan sepeda, bisa mencegah terjadinya kemacetan. Salah satu tindakan nyata pemerintah adalah adanya kewenangan pemerintah tentang jalur sepeda sebagai salah satu kebutuhan bagi masyarakat. Tujuan penelitian ini untuk mengungkap bentuk Kewenangan Pemerintah Kota Denpasar dalam mengefektifkan penerapan jalur sepeda dan bentuk perlindungan hukum terhadap pengguna jalur sepeda berdasarkan Undang-undang Nomor 22 Tahun 2009 di Perkotaan Denpasar. Tipe penelitian hukum yang digunakan pada penelitian ini adalah penelitian hukum empiris dengan pendekatan perundang-undangan. Adapun teknik pengumpulan data dilakukan dengan membaca, mencatat, mengutip, meringkas dan menganalisis data dan informasi yang diperoleh dari instansi terkait yaitu Dinas Perhubungan Kota Denpasar. Setelah mendapatkan bahan hukum primer dan bahan hukum sekunder yang kemudian diolah dan dianalisis secara sistematis, maka diperoleh data bahwa kewenangan pemerintah Kota Denpasar dalam mengefektifkan penggunaan jalur sepeda adalah dengan menyediakan fasilitas jalur sepeda di beberapa titik yang tersebar di wilayah Kota Denpasar, seperti di Jalan Sudirman, Jalan Letda Made Putra, Jalan Letda Tantular dan di beberapa titik lainnya. Sedangkan perlindungan hukum bagi pengguna jalur sepeda berisikan hak hak pe ngguna jalur sepeda, seperti disediakannya fasilitas jalur sepeda secara wajib oleh pemerintah untuk menjamin keamanan serta kenyamanan pesepeda, terbebasnya rasa takut dalam berlalu lintas, serta terhindarnya dari bahaya berlalu lintas.
\end{abstract}

Kata Kunci: Jalur Sepeda, Kewenangan, Perlindungan Hukum

\begin{abstract}
Realizing an environmentally friendly city of Denpasar is one of the balancing concepts in the development of an environmentally friendly city. Changing the mode of transportation to environmentally friendly transportation, such as the use of bicycles, can prevent congestion. One of the government's real actions is the government's authority on bicycle lanes as a necessity for the community. The purposes of this study are to reveal the form of authority of the Denpasar City Government in Streamlining the Application of Bicycle Paths and forms of legal protection for bicycle lane users based on Law Number 22 Year 2009 in Denpasar City. The type of legal research used in this research is empirical legal research with a statutory approach. The data collection techniques were carried out by reading, recording, quoting, summarizing and analyzing the data and information obtained from the relevant agencies, namely the Denpasar City Transportation Service. After obtaining primary legal materials and secondary legal materials which are then processed and analyzed systematically, data is obtained that the authority of the Denpasar City government in making the use of bicycle lanes effective is to provide bicycle lane facilities at several points scattered in the Denpasar City area, such as on Jalan Sudirman, Jalan Letda Made Putra, Jalan Letda Tantular and at several other points. Meanwhile, legal protection for bicycle lane users contains the rights of bicycle lane users, such as the mandatory provision of bicycle lane facilities by the government to ensure the safety and comfort of cyclists, freedom from fear in traffic, and avoidance oftraffic hazards.
\end{abstract}

Keywords: Cycling Path, Legal Protection, Authority

\section{PENDAHULUAN}

Di zaman modern saat ini, penggunaan kendaraan bermotor bukan lagi hal yang langka. Kendaraan bermotor dianggap faktor penting yang dapat mendukung aktivitas penggunanya yang membutuhkan mobilitas tinggi. Oleh sebab itu, tanpa disadari, peningkatan kebutuhan terhadap mobilisasi juga meningkatkan jumlah pengguna kendaraan di setiap tahunnya (Adisasmita, 2011). Peningkatan 
jumlah kendaraan di Indonesia, khususnya Bali, tidak hanya terjadi di kota besar, namun terjadi hampir merata di seluruh daerahnya.

Bali sebagai kawasan strategis, sebagai pulau yang terkenal dengan pariwisata, menjadi salah satu penyebab padatnya kendaraan di Pulau Bali. Berbagai macam keindahan pariwisata Bali menarik para wisatawan untuk datang ke Bali. Salah satu kota di Bali yang menjadi pusat kepadatan lalu lintas adalah Denpasar. Denpasar menjadi pusat kota di Bali menjadikan kepadatan lalu lintas tidak dapat terhindarkan. Secara umum faktor penyebab kemacetan di kawasan Denpasar adalah meningkatnya kepemilikan kendaraan bermotor. Khususnya kendaraan bermotor pribadi yang pergerakannya meningkat dalam ruang dan waktu, pengoperasian sarana angkutan umum yang kurang baik serta keterbatasan sumber daya untuk pembangunan jalan dan sarana angkutan lainnya. Hal tersebut terjadi karena di Kota Denpasar segala fasilitas pariwisata tersedia, seperti Mall, Pantai, Cafe, dan sebagainya. Selain fasilitas pariwisata yang lengkap, Kota Denpasar juga menjadi salah satu kota yang dipadati oleh pelajar. Hal tersebut karena Denpasar memiliki beberapa kampus yang menjadi tujuan para pelajar, baik pelajar yang merupakan warga Denpasar maupun pendatang dari daerah luar Denpasar. Pekerjaan yang beragam juga menjadikan Kota Denpasar memiliki lalu lintas yang padat karena kendaraan yang melintasi kota Denpasar tidak hanya kendaraan yang berasal dari Denpasar saja, melainkan kendaraan yang berasal dari luar Kota Denpasar juga ikut ambil andil terhadap kemacetan ini.

Di perkotaan yang memiliki penduduk yang cukup padat, kemacetan tidak bisa terhindari lagi. Kemacetan ini tidak hanya terjadi di jam-jam kerja saja namun juga terjadi pada jam-jam lenggang lainnya. Hal tersebut terjadi karena adanya peningkatan volume penggunaan kendaraan bermotor. Selain menimbulkan kemacetan, peningkatan penggunaan kendaraan bermotor juga berpengaruh kepada lingkungan. Wujud dari perkotaan yang lebih ramah lingkungan demi mewujudkan keseimbangan antara konsep lingkungan dan pesatnya pembangunan serta teknologi, menjadikan penggunaan kendaraan tidak bermotor menjadi salah satu solusi yang tepat (Komarudin, 1999).

Sepeda adalah salah satu teknologi ramah lingkungan sebagai alat transportasi tanpa bahan bakar yang juga sangat efektif dalam mewujudkan perkotaan yang berwawasan lingkungan. Sepeda mampu menggantikan kendaraan bermotor namun tetap memiliki fungsi yang sama, hanya saja penggunaan sepeda tanpa bahan bakar minyak ini mampu mengurangi resiko terjadinya pemanasan global (Setiadi, 2019). Tujuan dari pemerintah Indonesia adalah untuk memajukan kesejahteraan umum mempunyai peran strategis dalam mendukung pembangunan nasional dalam memajukan kesejahteraan umum tersebut. Perwujudan nyatanya, masih belum banyak perhatian baik dari masyarakat maupun pemerintah terhadap keamanan bersepeda. Akibatnya banyak menimbulkan kendala-kendala salah satunya seperti penyediaan infrastruktur yakni jalur sepeda yang belum rata ada di seluruh jalan perkotaan. Maka dari itu, hal tersebut menyebabkan timbulnya masalah-masalah yang berhubungan dengan keselamatan pesepeda. Maka dari permasalahan tersebut dibutuhkannya jalur khusus sepeda yang dipisah secara fisik dari jalur lalu lintas kendaraan bermotor dengan pagar pengaman ataupun ditempatkan secara terpisah dari jalan raya (Sugasta et al., 2017). Sebab sudah menjadi kewajiban pemerintah memenuhi fasilitas publik berupa jalur sepeda Undang-Undang Nomor 22 tahun 2009 tentang Lalu Lintas dan Angkutan Jalan sebagai dasar hukum yang telah mengatur bahwa setiap lalu lintas umum wajib dilengkapi fasilitas untuk sepeda. Aturan Undang-Undang tersebut juga diperkuat dengan adanya Peraturan Pemerintah Nomor 79 tahun 2013 tentang Jaringan Lalu lintas dan Angkutan Jalan yang mengatur tentang fasilitas sepeda (Asasi, 2019).

Penggunaan sepeda dijalan raya juga memiliki aturan-aturan yang tertuang dalam UndangUndang seperti penggunaan lajur sepeda. Lajur sepeda tertuang dalam UU Nomor 22 Tahun 2009 Tentang Lalu Lintas dan Angkutan Jalan. Pasal 25 menyatakan bahwa setiap jalan yang digunakan untuk lalu lintas umum wajib dilengkapi dengan perlengkapan jalan berupa fasilitas untuk sepeda, pejalan kaki, dan penyandang cacat. Pasal 45 menyatakan fasilitas pendukung penyelenggaraan lalu lintas dan angkutan jalan melewati lajur sepeda dan pemerintah harus memberikan kemudahan berlalu lintas bagi pesepeda. Pasal 62 menyatakan Pesepeda berhak atas fasilitas pendukung keamanan, keselamatan, ketertiban dan kelancaran dalam berlalu lintas. Selain itu, perancangan fasilitas lajur dan jalur sepeda juga terkait dengan UU Nomor 38 Tahun 2004 tentang Jalan dan Undang-undang Nomor 26 Tahun 2007 tentang Tata Ruang. Berdasarkan aspek legal tersebut, maka terdapat keharusan membangun lajur sepeda. Ketersediaan jalur sepeda di kawasan Kota Denpasar tepatnya di daerah 
Renon oleh pemerintah Kota Denpasar merupakan peningkatan akomodasi bagi pengendara sepeda demi meningkatkan keselamatan para pesepeda. Pemerintah Kota Denpasar mengurangi lebar jalan bagi kendaraan bermotor dan membuat lebar jalan bagi jalur khusus bagi pesepeda. Adanya fasilitas jalur sepeda ini menjadi salah satu langkah nyata pemerintah memberikan sarana bagi masyarakat khususnya, masyarakat yang menggunakan sepeda sebagai alat transportasi yang ramah lingkungan.

(Adiputra et al., 2018) wewenang pemerintahan adalah kekuasaan yang ada pada pemerintah untuk menjalankan fungsi dan tugasnya berdasar peraturan perundang undangan. Dengan kata lain, wewenang merupakan kekuasaan yang mempunyai landasan untuk mengambil tindakan atau perbuatan hukum agar tidak timbul akibat hukum, yakni terwujudnya kesewenang-wenangan (overmatig). Wewenang adalah kekuasaan hukum untuk menjalankan atau melakukan suatu tindakan atau perbuatan berdasar hukum publik. Jalur sepeda adalah suatu jalur khusus bagi pesepeda yang membuat penggunanya menjadi lebih aman, fasilitas lengkap dan lebih tertata di jalan raya, karena dengan adanya jalur sepeda dan fasilitas ini akan mengurangi resiko kecelakaan bagi pesepeda. Lajur sepeda yang berada pada jalur sepeda yang dibatasi oleh separator memberikan keluasan bagi pesepeda untuk bergerak dengan rasa aman dibandingkan jalur sepeda yang berada pada jalur jalan umum tanpa separator. Pada jalan umum tanpa separator atau keren, kendaraan bermotor dapat melewati atau mengambil alih lajur yang sudah disediakan bagi pesepeda. Pertimbangan penggunaan separator atau tidak harus dipertimbangkan secara bijak diantaranya dengan memperhatikan jumlah pesepeda, kondisi lalu lintas, dan lebar badan jalan.

Penempatan jalur sepeda dapat mempengaruhi kenyamanan pengguna, jika jalur sepeda digunakan bersamaan dengan jalur lalu lintas lain, seperti jalur pejalan kaki dan jalur bus, maka harus ada jalur yang sesuai, seperti menyediakan jalur khusus sepeda untuk menjamin keamanan dan kenyamanan pengguna sepeda. Rute jalur sepeda harus dirancang dalam jaringan yang terhubung dengan tujuan utama perjalanan, berupa ruang ruang publik. Rute dïnformasikan secara jelas mencakup rute alternatif yang tersedia beserta tempat-tempat istirahat yang disediakan.

Ada banyak pendekatan untuk desain jalur sepeda yaitu Jalur khusus sepeda adalah jalur dimana lalu lintas sepeda dipisahkan secara fisik dari jalur kendaraan bermotor melalui pagar pengaman atau ditempatkan secara terpisah di jalan dan Jalur sepeda sebagai bagian dari jalur jalan yang hanya dipisahkan oleh marka jalan atau warna jalan lain yang berbeda. Pembagian tipe fasilitas jalur dan lajur sepeda di Indonesia mengacu pada Rancangan Standar Nasional Indonesia (RSNI) Perancangan Fasilitas Lajur dan Jalur Sepeda terbagi atas tiga yaitu tipe A, tipe B, dan tipe C. Pembagian tipe tersebut berdasarkan pada penempatan dan pemisahan lajur sepeda. Tipe A yaitu lajur sepeda yang berada pada jalur sepeda atau jalur jalan namun dipisahkan dari kendaraan lain dengan separator (dapat berupa kereb). Tipe ini dapat ditempatkan pada kondisi lalu lintas dengan kecepatan kendaraan tinggi dan akses yang terbatas pada jalan. Tipe B yaitu lajur sepeda yang berada pada trotoar dan ditempatkan pada sisi sebelah kanan lajur pejalan kaki. Tipe B dapat ditempatkan pada kondisi lalu lintas kecepatan sedang dan rendah. Tipe $\mathrm{C}$ yaitu lajur sepeda yang berada pada lajur jalan dan ditandai dengan pemisah berupa marka jalan. Tipe $\mathrm{C}$ idealnya digunakan pada kondisi lalu lintas dengan kecepatan kendaraan rendah, dan akses keluar masuk bangunan di sepanjang jalan yang tinggi Berdasarkan dari Peraturan Daerah No. 27 Tahun 2011 kota Denpasar tentang Rencana Tata Ruang Wilayah Kota Denpasar Tahun 2011-2031, menyebutkan dalam pasal 20 ayat (2) huruf b tentang pemberian prioritas keselamatan dan kenyamanan bagi pengguna jalan khususnya pejalan kaki dan pengendara sepeda melalui penyediaan jalur khusus, dan pasal 35 ayat 1 huruf a tentang penyediaan jalur-jalur kegiataan prosesi keagamaan dan budaya, ayat 1 huruf $b$ penyediaan jalur sepeda, dan ayat 1 huruf c penyediaan jalur-jalur untuk penyandang cacat dan kaum disable lainnya.

Penelitian sebelumnya mengungkapkan bahwa Dinas Perhubungan mempunyai kewenangan untuk melakukan penertiban dengan pengawalan dari kepolisian, dengan kata lain instansi yang berkaitan saling berkerjasama untuk membangun keamanan dan ketertiban di kota Denpasar (Indrawan et al., 2016). Lebih lanjut, Peraturan Menteri Perhubungan (PM) No 59 Tahun 2020 tentang Keselamatan Pesepeda di Jalan. Sebagai turunan dari Undang undang No 22 Tahun 2009 tentang Lalu Lintas dan Angkutan Jalan Pasal 45 bahwa fasilitas pendukung penyelenggaraan lalu lintas dan angkutan jalan meliputi lajur sepeda (Wirawan, 2021). Dalam pasal 62 juga disebutkan bahwa pemerintah harus memberikan kemudahan berlalu lintas bagi pesepeda. Pesepeda berhak atas fasilitas pendukung keamanan, keselamatan, ketertiban, dan kelancaran dalam berlalu lintas (Prasetyo et al., 2020). Maka berdasarkan penelitian sebelumnya, bentuk Kewenangan Pemerintah Kota 
Denpasar dalam mengefektifkan penerapan jalur sepeda dan bentuk perlindungan hukum terhadap pengguna jalur sepeda berdasarkan Undang-undang Nomor 22 Tahun 2009 di Perkotaan Denpasar belum terungkap dan hal ini menjadi suatu tujuan penelitian guna menginformasikan lebih lanjut kepada pemerintah maupun masyarakat terkait kasus tersebut.

\section{METODE PENELITIAN}

Tipe penelitian hukum yang digunakan pada penelitian ini adalah penelitian hukum empiris dengan pendekatan perundang-undangan untuk mengetahui dan menentukan aturan hukum sebagai bentuk kewenangan pemerintah Kota Denpasar dalam mengefektifitaskan penggunaan jalur khusus sepeda. Pendekatan kasus dalam penelitian ini digunakan untuk menganalisis kecocokan dalam peristiwa hukum yang ada dengan pandangan-pandangan argumentasi hukum dalam memecahkan sebuah kasus yang dihadapi. Teknik pengumpulan data yang digunakan dalam penelitian ini adalah teknik pengumpulan data dengan cara pengambilan keputusan, yaitu dengan membaca, mencatat, mengutip, meringkas dan menganalisis data dan informasi yang diperoleh dari instansi terkait yaitu Dinas Perhubungan Kota Denpasar, serta mengkajinya sesuai dengan peraturan perundang-undangan dan literatur yang terkait dengan masalah tersebut. Penelitian ini akan dilakukan di Kantor Dinas Perhubungan, Padang Sambian Kaja, Denpasar Barat, Jl. Gn. Galunggung, Ubung Kaja, Denpasar City, Bali 80116. Setelah mendapatkan bahan hukum primer dari hasil wawancara di Dinas Perhubungan Kota Denpasar dan bahan hukum sekunder dari buku-buku, jurnal-jurnal dan hasil-hasil penelitian terdahulu yang memiliki keterkaitan dengan judul penulisan ini yang kemudian diolah dan dianalisis secara sistematis.

\section{HASIL DAN PEMBAHASAN}

\section{Bentuk Kewenangan Pemerintah Kota Denpasar dalam Mengefektifkan Penerapan Jalur Sepeda}

Masih tingginya minat masyarakat untuk menggunakan sepeda sebagai salah satu teknologi ramah lingkungan, dapat dilihat dari penggunaan sepeda oleh berbagai kalangan usia. Berdasarkan hasil survey lapangan diperoleh data 100 responden. Dari jumlah responden tersebut dapat teridentifikasi dengan rincian mayoritas responden berusia 20 tahun keatas kemudian disusul oleh usia 20 tahun kebawah. Mayoritas responden berasal dari Denpasar sedangkan sebagiannya berasal dari luar wilayah Denpasar, seperti Klungkung, Jimbaran, Gianyar dan Tabanan. 53\% masyarakat menggunakan sepeda untuk kepentingan olahraga dan rekreasi, dan yang lainnya sebagai sarana transportasi seperti untuk kegiatan sosial. Data kepemilikan sepeda, 96\% mayoritas sepeda merupakan milik pribadi. Bagi responden penggunaan sepeda memang bukan menjadi moda transportasi utama dalam kehidupan sehari hari, namun penggunaan sepeda mampu menjadi pilihan alternatif untuk transportasi ramah lingkungan.

Dari data survey lingkungan yang diperoleh, mayoritas responden memberikan alasan setuju terhadap pengembangan jalur sepeda dengan alasan menciptakan kenyamanan, keamanan dan keselamatan yakni 35\%, kemudian disusul dengan alasan memfasilitasi masyarakat dengan jalur khusus sepeda. Dengan berbagai respon positif responden terhadap pengembangan jalur sepeda, maka pengembangan jalur sepeda sudah menjadi opsi terbaik bagi pemerintah. Wawancara dengan I Gede Hardana, S.H. selaku pesepeda menyebutkan belum $100 \%$ memenuhi fasilitas jalur sepeda secara merata, karena beberapa jalur yang di buat kondisinya ada yang tidak layak dilewati seperti jalan berlubang dan bekas galian yg belum ditutup atau diratakan yang berpotensi menjadi bahaya bagi pengguna sepeda, namun fasilitas jalur sepeda yang disediakan pemerintah, sudah dapat dirasakan manfaatnya terbukti pesepeda lebih tertib di jalan dan aman untuk melintas di jalan karena adanya jalur khusus sepeda. Masih sedikit jalur sepeda yang disediakan di Kota Denpasar, masih kurangnya kesadaran para pengguna jalan lain (pemotor) dalam berkendara dengan menggunakan jalur sepeda serta memberi klakson peringatan saat sepeda berada di depan padahal jalur yg dilewati adalah jalur khusus sepeda, serta masih ada mobil yang terparkir di jalur sepeda sehingga dapat menimbulkan bahaya bagi pesepeda karena jalur yg digunakan semakin sempit Pemerintah Kota Denpasar berdasarkan kewenangannya mengatasi permasalahan yang berkaitan dengan lalu lintas dan angkutan jalan sesuai dengan Keputusan Walikota Nomor 23 Tahun 2019 Tentang Perubahan Atas Peraturan Walikota Nomor 44 Tahun 2016 Tentang Kedudukan Susunan Organisasi, Tugas Dan Fungsi Serta 
Tata Kerja Dinas Daerah, menyatakan bahwa Dinas Perhubungan Kota Denpasar memiliki tugas pokok dan fungsi dalam melaksanakan kewenangan otonomi daerah di bidang perhubungan.

Petugas yang diberikan kewenangan melalui instansinya untuk mengatasi masalah masalah lalu lintas, berwenang untuk memelihara kedamaian dalam masyarakat. Erwinsyahbana \& Melinda (2018) secara yuridis kewenangan diartikan sebagai suatu kemampuan yang diberikan peraturan perundang undangan yang berlaku untuk menimbulkan akibat akibat hukum. Untuk melaksanakan kekuasaan, tugas serta amanat maka diperlukanlah kewenangan. Kewenangan yang bersumber dari perundang undangan dapat diperoleh melalui tiga cara, yaitu atribusi, delegasi dan mandat. Petugas yang diberikan kewenangan dalam hal ini harus memiliki pengetahuan serta pemahaman yang profesional mengenai masalah masalah dalam bidang lalu lintas. Berdasarkan pasal 6 huruf $\mathrm{g}$ Peraturan Daerah Nomor 7 Tahun 2008 Tentang Organisasi Dan Tata Kerja Dinas Daerah Kota Denpasar, petugas dari instansi yang bertugas menangani masalah masalah lalu lintas dan angkutan jalan adalah Dinas Perhubungan. Dinas Perhubungan Kota Denpasar dalam melaksanakan kewenangannya, memiliki bagian bagian organisasi sesuai dengan ketentuan. Bidang yang bertugas menangani masalah lalu lintas dalam hal penggunaan jalur sepeda ialah bidang lalu lintas.

Berdasarkan Dinas Perhubungan Kota Denpasar jalur sepeda sudah ada sebanyak 35 jalur khusus sepeda dan tersebar di beberapa titik Kota Denpasar baik yang sudah beroperasi dan bisa digunakan maupun yang masih dalam tahap pembangunan. Penyediaan jalur khusus sepeda di Kota Denpasar tersebar dengan panjang rute yang berbeda beda. Jalur khusus sepeda dengan rute terpanjang terdapat di jalan Raya Puputan dengan panjang 3.340 m. Perawatan jalur khusus sepeda di Kota Denpasar terlihat kurang merata. Hal tersebut karena terdapat beberapa titik jalur khusus sepeda yang kondisinya pudar bahkan sudah tertutup aspal.

\section{Bentuk Perlindungan Hukum Terhadap Pengguna Jalur Sepeda Berdasarkan Undang-undang Nomor 22 Tahun 2009 di Perkotaan Denpasar}

Perlindungan hukum terhadap pengguna jalur sepeda yang tertuang dalam Undang-undang Nomor 22 Tahun 2009 Tentang Lalu Lintas dan Angkutan Jalan adalah segala upaya yang ditujukan untuk memberikan rasa aman, nyaman kepada pengguna jalur lalu lintas. Perlindungan hukum yang dimaksud yaitu perlindungan oleh hukum dengan menggunakan pranata dan sarana hukum dalam membuat peraturan yang berisikan hak dan kewajiban serta menjamin hak hak subyek hukum sehingga bersifat permanen karena sifatnya yang konstitusional, sehingga mampu diakui dan ditaati keberadaannya di masyarakat. Berdasarkan Undang-undang Nomor 22 Tahun 2009 tersebut, pengguna jalur sepeda telah mendapatkan perlindungan hukum yang berisikan hak hak pengguna jalur sepeda, seperti disediakannya fasilitas jalur sepeda secara wajib oleh pemerintah untuk menjamin keamanan serta kenyamanan pesepeda, terbebasnya rasa takut dalam berlalu lintas, serta terhindarnya dari bahaya berlalu lintas.

Keamanan yang dimaksud yaitu meliputi proteksi fisik, pemenuhan standar dimensi, rancangan simpang, pengendalian kecepatan. Kelangsungan rute meliputi perancangan rute yang lebih singkat dibandingkan kendaraan bermotor dan pemberian prioritas bagi pesepeda di penyebrangan dan persimpangan. Keterpaduan meliputi pembuatan rute menerus dan tidak terputus dari titik awal ke tujuan pesepeda, penyediaan marka yang jelas dan menyediakan fasilitas parkir di tempat-tempat tujuan pesepeda. Kenyamanan meliputi pembuatan permukaan lajur sepeda yang rata serta tidak licin, pembuatan lebar yang cukup pada lajur sepeda sehingga memungkinkan pesepeda untuk mendahului atau bersepeda berdampingan. Kenyamanan pengguna sepeda sangat bergantung kepada ruang gerak bebasnya semakin besar ruang geraknya maka akan lebih nyaman dalam melakukan aktivitas bersepeda.

\section{SIMPULAN DAN SARAN}

\section{Simpulan}

Kewenangan Pemerintah kota Denpasar untuk mengefektifkan penerapan jalur khusus sepeda adalah dengan mengeluarkan Peraturan Daerah No. 27 Tahun 2011 kota Denpasar tentang Rencana Tata Ruang Wilayah Kota Denpasar Tahun 2011-2031, menyebutkan dalam pasal 20 ayat (2) huruf b tentang pemberian prioritas keselamatan dan kenyamanan bagi pengguna jalan khususnya pejalan kaki dan pengendara sepeda melalui penyediaan jalur khusus, dan pasal 35 ayat (1) huruf a tentang penyediaan jalur-jalur kegiataan prosesi keagamaan dan budaya, ayat (1) huruf $b$ penyediaan jalur 
sepeda, dan ayat (1) huruf c penyediaan jalur-jalur untuk penyandang cacat dan kaum disable lainnya, dalam pengawasannya dilakukan oleh Dinas Perhubungan Kota Denpasar sesuai dengan Keputusan Walikota Nomor 23 Tahun 2019 Tentang Perubahan Atas Peraturan Walikota Nomor 44 Tahun 2016 Tentang Kedudukan Susunan Organisasi, Tugas Dan Fungsi Serta Tata Kerja Dinas Daerah. Adapun perlindungan hukum terhadap pengguna jalur sepeda adalah suatu perlindungan yang diberikan kepada pengguna jalur sepeda baik yang bersifat preventif maupun yang bersifat represif Perlindungan hukum terhadap pengguna jalur sepeda tertuang dalam Undang-undang Nomor 22 tahun 2009 tentang lalu lintas dan angkutan jalan, dengan adanya aturan ini memberikan kemudahan bagi pesepeda ataupun pejalan kaki, dan lalu lintas akan semakin tertata sehingga pelanggaran-pelanggaran akan semakin berkurang karena adanya Undang-undang tersebut.

\section{Saran}

Kewenangan pemerintah untuk mengefektifkan penggunaan jalur sepeda yang telah ada berdasarkan keterangan Perwali perlu dilakukan pengawasan dan pelaksanaannya, agar tidak terjadi pengalihan fungsi dan tidak ada penularan secara berlanjut. Perlindungan hukum bagi pengguna jalur sepeda agar dapat terlindungi dengan baik, dengan adanya kerja sama menjaga fasilitas yang diberikan oleh pemerintah kota Denpasar dan memiliki kenyamanan bagi pengguna jalur sepeda, sehingga pengguna jalur sepeda nyaman menggunakan fasilitas yang diberikan oleh pemerintah kota Denpasar dan pemerintah lebih mengamati terkait jalur sepeda tersebut dan benar-benar dapat melindungi penggunanya.

\section{DAFTAR PUSTAKA}

Adiputra, I. M. P., Utama, S., \& Rossieta, H. (2018). Transparency of local government in Indonesia. Asian Journal of Accounting Research, 3(1), 123-138.

Adisasmita, S. A. (2011). Transportasi dan Pengembangan Wilayah. Graha Ilmu, Yogyakarta.

Asasi, A. N. (2019). Pandangan Komunitas Bike To Work Semarang Terhadap Fasilitas Jalur Sepeda di Kota Semarang. Journal of Politic and Government Studies, 8(4), 1-6.

Erwinsyahbana, T., \& Melinda. (2018). Kewenangan dan Tanggung Jawab Notaris Pengganti setelah Pelaksanaan Tugas dan Jabatan Berakhir. Lentera Hukum, 5(2), 324-339.

Indrawan, A. A. B., Punia, I. N., \& Nugroho, W. B. (2016). Persepsi Masyarakat tentang Keselamatan Pengguna Jalur Khusus Sepeda Motor di Jalan Raya Kota Denpasar. Jurnal Ilmiah Sosiologi, $1(1), 1-14$.

Komarudin. (1999). Pembangunan Perkotaan Berwawasan Lingkungan. Direktorat Jenderal Cipta Karya Departemen Pekerjaan Umum.

Prasetyo, A., Nugroho, M. W., Amudi, A., \& Yulianto, T. (2020). Kajian Awal Perencanaan Lajur Khusus Sepeda Dengan Menggunakan Metode IPA (Importance Performance Analysis) dan SWOT. Proteksi, 2(2), 41-47.

Setiadi, P. (2019). Solilokui Sepeda. Dahara, Jakarta.

Sugasta, H. H., Widodo, S., \& Mayuni, S. (2017). Analisis Efektivitas Lajur Khusus Sepeda Pada Kawasan Perkotaan Pontianak (Studi Kasus Jalan Sutan Syahrir - Jalan Jendral Urip - Jalan K. H. W. Hasyim - Jalan Merdeka). JeLAST : Jurnal PWK, Laut, Sipil, Tambang, 4(4), 1-9.

Wirawan, K. (2021). Perencanaan Jalur Sepeda Berdasarkan Persepsi dan Preferensi Wisatawan Bersepeda di Pantai Sanur Bali. Jurnal Inovasi Penelitianleitian, 1(8), 1535-1542. 